\title{
Special problems in COCM: South America
}

\author{
D. S. AMORIM \\ M.D. \\ Department of Medicine, University of São Paulo, Brazil
}

WHILE this study is closely concerned with the cardiomyopathies, it is also bounded to specific aspects of the problem of social development. In particular, the study concentrates upon a disease which involves some degree of spatial and social adjustment, but it cannot neglect the changes which modify existing geographical distribution of diseases and the eventual relations between different areas.

Compared with Africa and Asia, the South American continent appears to be quite highly 'developed' (per capita income and other welfare indicators). At the same time, it appears far from developed if compared with Europe and North America. Such generalizations, however, hide some important distinctions and ignore the vast differences that exist between the various parts of the continent (Gilbert, 1977).

South America is in several ways heterogeneous. But, if this is so, why continue to imply that it represents a single entity, at least for the purpose of academic discussion? The answer is that while strong differences exist within the continent, the many common social, cultural and economic phenomena justify, within limits, treating it as a single entity. Nevertheless, it would be a gross mistake to ignore regional differences and that particular spatial phenomena are more fully developed or better documented.

During the past two decades the rate of urban growth has been very rapid. By 1980 , the share of the population living in urban areas is likely to have increased from $39.1 \%$ in 1950 to $60.7 \%$ (UN ECLA, 1969). Today foreign immigration is negligible, and everywhere it is rural-urban migration and high-rates of natural increase that are the principal factors behind urban growth. To generalize about the impact of emigration upon an area involves taking into account a whole complex of factors.

The reasons why geographical aspects should be involved in a discussion on cardiomyopathies have already been given by Hutt (1972). He emphasized that by comparing differences in the incidence or prevalence of a disease one may pick up clues to its aetiology. But it is quite clear that emigration from the poor Latin American rural areas alters patterns of health and disease in both urban and rural areas. $\overrightarrow{\vec{\omega}}$

The Pan-American Health Organization surveyo on causes of death showed that cardiovascularo diseases hold a position of prominence among the causes of morbidity and mortality of adult popula- $\rightarrow$ tion (Puffer and Griffith, 1967). The investigation ${ }_{\mathcal{E}}^{\circ}$ was designed to present data on mortality for twelve ${ }^{\mathrm{U}}$ widely separated cities which would not only beक् accurate but also comparable. In the survey the viewo of mortality by major groups of causes revealed marked geographical differences, which warrant ${ }_{c}$ careful interpretation and further study. Neverthless the analysis shows the very great range of mortality from infective and parasitic diseases, certainly one $8 f^{\circ}$ the leading problems being Chagas' disease.

Chagas' disease is essentially an endemic infection? of rural population and has a defined geographicals distribution. The disease is known to be widespreado in Brazil and cases have also been reported froma several countries of Latin America, but reliable $e_{\propto}^{\Phi}$ epidemiological data are yet not available.

What evidence there is suggests that there are nearly 35 million people exposed to the risk of infection (WHO, 1960). It is difficult to get reliable and comparable figures of the prevalence from different parts, partly because serological studies are 3 not always available. For the sake of illustration results from rural areas of Brazil (Pedreira de 3 . Freitas, 1965) and two rural areas of Venezuela (Puigbó et al., 1966) have shown, respectively, $39.1,39.7$ and $47.3 \%$ of their populations beingo sero-positive. In its chronic phase, cardiac pathology? is the most common and serious complication of theo disease.

Until quite recently, some authors were com- $N$ plaining that the spatial component had been neglected in planning studies. In particular, it wasu claimed that the pattern of cardiovascular diseases $\omega$ in large cities had been ignored. New work has appeared which has examined this problem by com $-\frac{0}{0}$ paring differences (Laurenti and Fonseca, 1976).

In the city of São Paulo, Brazil, deaths from cardiovascular diseases accounted for $16.1 \%$ of alb deaths (overall 209.7/100 000 inhabitants) in 1940, while in 1969 that number had increased to $30.2 \%$ 
(overall 258.4/100 000 inhabitants). Comparing these figures with those of some other developed countries it will be concluded that in the latter there are higher rates. Considering the different pathologies, ischaemic heart disease $(11.5 \%)$, cerebrovascular accidents $(9 \cdot 1 \%)$, systemic arterial hypertension $(2 \cdot 8 \%)$ and rheumatic heart disease $(1.3 \%)$ accounted for $68.5 \%$ of all deaths due to cardiovascular diseases (Laurenti and Fonseca, 1976).

Unfortunately, without casting doubts on these figures, there are certain deficiencies which may have encouraged false conclusions and therefore warrant further studies.

Having suggested that there may be reasons for the pattern, it is pertinent to understand how and why the city social and demographic growing lends itself to modifications. Certainly, there are a large number of migrants who moved from rural areas and therefore their origins should reflect in the pattern of cardiovascular diseases.

This pattern may be compared with the other, reported by the Pan-American Health Organization, related to Ribeirão Preto (Puffer and Griffith, 1967). This city of approximately 250000 inhabitants is $300 \mathrm{~km}$ from the city of São Paulo. In Ribeirão Preto, Chagas' disease was responsible for $13 \%$ of all deaths. Numerically it was more important than any of the following causes: tuberculosis, cerebrovascular accidents, ischaemic heart disease, diseases of the respiratory system, all forms of digestive diseases and all external causes of death. The excessive high death rates from Chagas' disease in this population were well supported by the recorded diagnostic evidence and must therefore be accepted as real. Chagas' disease was probably more readily recognized in Ribeirão Preto than elsewhere, remaining questionable whether an equal awareness exists in other cities.

The reason why an infective disease should be involved in a discussion on cardiomyopathies, is because in its chronic phase, cardiac involvement is the most frequent and serious complication of the disease. Also to a large extent the clinical concept of chronic Chagas' heart disease is of a pathology characterized by congestive failure with poor systolic function.

The condition about to be discussed must be briefly defined: Trypanosoma cruzi infection may occur at any age, but usually in the first years of life. Cardiac involvement of greater or lesser intensity probably occurs in almost every acute case, but it seems not to be frequently recognized. Postmortem examination shows an acute, severe, diffuse myocarditis with $T$. cruzi in myocardial fibres in all the cases (Laranja et al., 1956).

From a group of patients with a known acute period of infection, $22 \cdot 7 \%$ developed electrocardio- graphic changes during an average period of 10 years after the acute infection (Laranja et al., 1956). The age distribution of chronic Chagas' cardiopathy shows that nearly $50 \%$ of these cases are between 21 and 40 years of age. Focal and diffuse fibrosis of the myocardium is almost invariably present. Inflammatory reactions and foci of parasites are extremely rare in the chronic phase (Köberle, 1963).

The two conditions, acute myocarditis and chronic cardiopathy, have an intimate aetiological relationship. However, it goes without saying that chronic cardiopathy is in direct continuity with a previous myocarditis. It must be emphasized that patients who survive the acute phase remain apparently healthy and asymptomatic for decades before an established clinical diagnosis of heart involvement is made.

The most common recognized clinical signs in chronic Chagas' heart disease are cardiomegaly, cardiac failure, conduction disturbances and in the repolarization phase of the ECG. The same variety of abnormalities is disclosed by all the reported groups of cases in which the diagnosis was made on a similar basis (e.g. Dias, Laranja and Nobrega, 1945; Rosenbaum and Alvarez, 1955). However, there are discrepancies in relation to the percentage of abnormal tracings and in relation to the frequency of the visible changes. Although the extraordinary high incidence of right bundle branch block $(30-55 \%)$ and the great frequency of pronounced left-axis deviation in chagasic right bundle branch block (Tranchesi et al., 1971), these electrocardiographic findings are non-specific.

In spite of the overwhelming preponderance of the cardiac pathology, as reported by others and shown here, there were a number of patients with sole involvement of hollow viscera and association of cardiac and digestive disorders (Köberle, 1963).

Over a period of 10 years the author studied a large number of cardiac chagasic patients, the results now presented were obtained from 120 chagasic individuals. A larger number of clinically similar patients seen by the author, but not subjected to cardiac catheterization, are not included. All these individuals had a positive serology.

Results (Tables 1 and 2) reveal that several patients (Group III, $n$ 30) had the haemodynamic features of congestive cardiomyopathy, in accord with those previously reported (Amorim et al., 1968a): decreased cardiac output and stroke volume, and raised systemic and pulmonary venous pressures. However, the data show that a large number of patients with no past or present history of cardiac decompensation (Group II, $n$ 40) had resting haemodynamic data within the range for normal individuals. Normal values were also found in noncardiac (megalo-oesophagus, megacolon) chagasic 
TABLE 1. Summary on resting haemodynamics

\begin{tabular}{|c|c|c|c|c|c|c|c|}
\hline & $\underset{\mathbf{m}}{\mathbf{R A}}$ & $\begin{array}{l}\text { RV } \\
\text { S/D }\end{array}$ & $\begin{array}{r}\text { PA } \\
\text { S/D }\end{array}$ & WP & $\begin{array}{r}\text { SA } \\
\text { S/D }\end{array}$ & PVR & SVR \\
\hline \multicolumn{8}{|l|}{ GrouP I } \\
\hline Mean (s.d.) & $\begin{array}{l}2 \cdot 2 \\
(1 \cdot 87)\end{array}$ & $\begin{array}{c}21 \cdot 3 / 1 \cdot 7 \\
(4 \cdot 89 / 1 \cdot 66)\end{array}$ & $\begin{array}{c}20 \cdot 5 / 7 \cdot 7 \\
(4 \cdot 25 / 2 \cdot 06)\end{array}$ & $\begin{array}{l}5 \cdot 5 \\
(2 \cdot 68)\end{array}$ & $\begin{array}{c}122 \cdot 8 / 68 \cdot 0 \\
(15 \cdot 19 / 11 \cdot 03)\end{array}$ & $\begin{array}{l}157 \cdot 8 \\
(48 \cdot 15)\end{array}$ & $\begin{array}{c}1,185 \cdot 3 \\
(276 \cdot 84)\end{array}$ \\
\hline \multicolumn{8}{|l|}{ GrouP II } \\
\hline Mean (s.d.) & $\begin{array}{l}2 \cdot 7 \\
(1 \cdot 84)\end{array}$ & $\begin{array}{c}23 \cdot 6 / 2 \cdot 4 \\
(4 \cdot 75 / 1 \cdot 92)\end{array}$ & $\begin{array}{c}21 \cdot 2 / 7 \cdot 2 \\
(4 \cdot 39 / 2 \cdot 50)\end{array}$ & $\begin{array}{l}6 \cdot 1 \\
(2 \cdot 32)\end{array}$ & $\begin{array}{c}126 \cdot 5 / 68 \cdot 2 \\
(15 \cdot 95 / 9 \cdot 86)\end{array}$ & $\begin{array}{l}158 \cdot 6 \\
(61 \cdot 82)\end{array}$ & $\begin{array}{l}1,258 \cdot 6 \\
(413 \cdot 57)\end{array}$ \\
\hline \multicolumn{8}{|l|}{ GrouP III } \\
\hline Mean (s.d.) & $\begin{array}{l}10 \cdot 7 \\
(7 \cdot 75)\end{array}$ & $\begin{array}{c}42 \cdot 8 / 11 \cdot 7 \\
(15 \cdot 47 / 8 \cdot 48)\end{array}$ & $\begin{array}{c}43 \cdot 1 / 21 \cdot 2 \\
(14 \cdot 76 / 10 \cdot 43)\end{array}$ & $\begin{array}{l}15 \cdot 7 \\
(7 \cdot 89)\end{array}$ & $\begin{array}{c}117 \cdot 2 / 73 \cdot 0 \\
(20 \cdot 00 / 12 \cdot 97)\end{array}$ & $\begin{array}{c}850 \cdot 5 \\
(476 \cdot 87)\end{array}$ & $\begin{array}{l}2,343 \cdot 5 \\
(787 \cdot 52)\end{array}$ \\
\hline Mean (s.d.) & $\begin{array}{l}6 \cdot 0 \\
(4 \cdot 04)\end{array}$ & $\begin{array}{c}33 \cdot 8 / 6 \cdot 9 \\
(8 \cdot 77 / 4 \cdot 08)\end{array}$ & $\begin{array}{c}32 \cdot 5 / 7 \cdot 5 \\
(8 \cdot 363 \cdot 91)\end{array}$ & $\begin{array}{l}11 \cdot 4 \\
(4 \cdot 42)\end{array}$ & $\begin{array}{c}151 \cdot 5 / 62 \cdot 2 \\
(31 \cdot 75 / 16 \cdot 26)\end{array}$ & $\begin{array}{c}330 \cdot 2 \\
(170 \cdot 51)\end{array}$ & $\begin{array}{l}1,945 \cdot 6 \\
(809 \cdot 32)\end{array}$ \\
\hline
\end{tabular}

$\mathrm{RA}=$ right atrium; $\mathrm{RV}=$ right ventricle; $\mathbf{P A}=$ pulmonary artery; $\mathrm{WP}=$ 'wedge' pulmonary; $\mathbf{S A}=$ systemic artery $\mathbf{S}=$ systolic pressure; $\mathrm{D}=$ diastolic pressure; $\mathrm{m}=$ mean pressure. Cardiovascular pressure in $\mathrm{mmHg} ; \mathrm{PVR}=$ pulmonary vascular resistance; $\mathrm{SVR}=$ systemic vascular resistance. Vascular resistance in dynes $\mathrm{sec}^{-1} \mathrm{~cm}^{-5}$. Clinical characteristics of Groups I to IV are described in the text.

TABLE 2. Summary on resting haemodynamics

\begin{tabular}{|c|c|c|c|c|c|c|c|c|c|c|}
\hline & BS & HR & $\mathbf{R} \mathbf{R}$ & $\mathrm{Vo}_{2}$ & $\mathrm{O}_{2} \mathrm{a}$ & $\mathrm{O}_{2 \mathrm{v}}$ & AV & $\mathrm{O}_{2 \text { cap }}$ & CI & SI \\
\hline GROUP I & & & & & & & & & & \\
\hline Mean (s.d.) & $\begin{array}{c}1.57 \\
(0 \cdot 15)\end{array}$ & $\begin{array}{l}82.7 \\
(13 \cdot 20)\end{array}$ & $\begin{array}{l}18 \cdot 1 \\
(4 \cdot 04)\end{array}$ & $\begin{array}{l}232 \cdot 5 \\
(52.97)\end{array}$ & $\begin{array}{l}93 \cdot 9 \\
(2 \cdot 93)\end{array}$ & $\begin{array}{l}72 \cdot 1 \\
(7 \cdot 36)\end{array}$ & $\begin{array}{l}4 \cdot 0 \\
(0 \cdot 93)\end{array}$ & $\begin{array}{l}18 \cdot 0 \\
(2 \cdot 43)\end{array}$ & $\begin{array}{c}3 \cdot 7 \\
(0 \cdot 60)\end{array}$ & $\begin{array}{c}46.4 \\
(21.93)\end{array}$ \\
\hline GROUP II & & & & & & & & & & \\
\hline Mean (s.d.) & $\begin{array}{c}1.63 \\
(0.02)\end{array}$ & $\begin{array}{c}78 \cdot 0 \\
(13 \cdot 08)\end{array}$ & $\begin{array}{l}18 \cdot 6 \\
(3 \cdot 45)\end{array}$ & $\begin{array}{l}222 \cdot 8 \\
(65 \cdot 89)\end{array}$ & $\begin{array}{l}95 \cdot 5 \\
(2 \cdot 12)\end{array}$ & $\begin{array}{l}76 \cdot 2 \\
(6 \cdot 96)\end{array}$ & $\begin{array}{l}3 \cdot 6 \\
(1 \cdot 05)\end{array}$ & $\begin{array}{l}19 \cdot 0 \\
(2 \cdot 05)\end{array}$ & $\begin{array}{c}3 \cdot 6 \\
(1.02)\end{array}$ & $\begin{array}{c}47 \cdot 8 \\
(13 \cdot 87)\end{array}$ \\
\hline $\begin{array}{l}\text { GrouP III } \\
\text { Mean (s.d.) }\end{array}$ & $\begin{array}{l}1 \cdot 58 \\
(0 \cdot 15)\end{array}$ & $\begin{array}{c}98 \cdot 0 \\
(19 \cdot 83)\end{array}$ & $\begin{array}{l}22 \cdot 5 \\
(7 \cdot 40)\end{array}$ & $\begin{array}{l}233 \cdot 4 \\
(54 \cdot 30)\end{array}$ & $\begin{array}{l}90 \cdot 4 \\
(6 \cdot 19)\end{array}$ & $\begin{array}{c}47 \cdot 8 \\
(15 \cdot 49)\end{array}$ & $\begin{array}{c}7 \cdot 8 \\
(2 \cdot 78)\end{array}$ & $\begin{array}{l}18 \cdot 2 \\
(1 \cdot 95)\end{array}$ & $\begin{array}{l}2 \cdot 1 \\
(0 \cdot 80)\end{array}$ & $\begin{array}{l}22 \cdot 0 \\
(7 \cdot 73)\end{array}$ \\
\hline $\begin{array}{l}\text { GrouP IV } \\
\text { Mean (s.d.) }\end{array}$ & $\begin{array}{c}1.59 \\
(0.14)\end{array}$ & $\begin{array}{l}39 \cdot 3 \\
(3 \cdot 55)\end{array}$ & $\begin{array}{l}20 \cdot 6 \\
(3 \cdot 62)\end{array}$ & $\begin{array}{l}199 \cdot 3 \\
(50 \cdot 19)\end{array}$ & $\begin{array}{l}95 \cdot 8 \\
(2 \cdot 30)\end{array}$ & $\begin{array}{c}69 \cdot 2 \\
(11 \cdot 17)\end{array}$ & $\begin{array}{l}5 \cdot 1 \\
(2 \cdot 25)\end{array}$ & $\begin{array}{l}18 \cdot 6 \\
(2 \cdot 03)\end{array}$ & $\begin{array}{l}2 \cdot 6 \\
(0 \cdot 84)\end{array}$ & $\begin{array}{l}69 \cdot 4 \\
(21 \cdot 27)\end{array}$ \\
\hline
\end{tabular}

BS = body surface $\left(\mathrm{m}_{2}\right) ; \mathrm{HR}=$ heart rate (beats $\left./ \mathrm{min}\right) ; \mathbf{R R}=$ respiration rate (cycles/min); $\mathrm{Vo}_{2}=$ oxygen consumption $(\mathrm{ml} /$ $\min$ STPD); $\mathrm{O}_{2} \mathrm{a}=$ arterial blood oxygen saturation; $\mathrm{O}_{2 \mathrm{v}}=$ mixed venous blood oxygen saturation; $\mathrm{AV}=\mathrm{systemic}$ arteriovenous blood oxygen difference $(\mathrm{ml} / 100 \mathrm{ml}) ; \mathrm{O}_{2}$ cap. $=$ blood oxygen capacity; $\mathrm{CI}=$ cardiac index $\left(\right.$ litres $\left./ \mathrm{min} / \mathrm{m}^{2}\right) ; \mathrm{SI}=\mathrm{stroke}$ index $\left(\mathrm{ml} /\right.$ beat $\left./ \mathrm{m}^{2}\right)$. Clinical characteristics of Groups I to IV are described in the text.

patients (Group I, $n$ 30). The importance of $T$. cruzi infection as a cause of complete atrioventricular block (Andrade, 1973; Amorim et al., 1975) is such that the author has analysed it as a separate group (Group IV, $n$ 20). The magnitude of changes in resting haemodynamics in the $A-V$ block patients varied in accordance with the clinical situation, i.e. where there was the likelihood of associated marked myocardial involvement.

A patient with cardiomyopathy often presents with evidence of heart failure in the absence of apparent underlying cause, as a likely result from disease of the heart muscle itself. It was generally thought that Chagas' disease was a chronic myocarditis. However, a chronic inflammatory infiltrate is out of proportion with the degenerative changes and, therefore, the resulting clinical picture. Routine examination of the heart often fails to disclose any reason for its frequent severe dilatation and hypertrophy.
The exact mechanism of the pathogenesis of Chagas' disease remains unknown. The various theories proposed to explain the pathogenic action of $T$. cruzi in the human organism (e.g. Chagas and Villela, 1922; Torres, 1941; Britto and Vasconcelos, 1954; Köberle, 1957; Muniz et al., 1970) include vascular, toxic, inflammatory, neurogenic and immunological pathways.

The author's investigations of cardiac cases have concentrated particularly on autonomic impairment. The physiological consequences of a possible loss or impairment of autonomic control (Amorim et al., 1968b; Manço et al., 1969; Gallo et al., 1975; Marin Neto et al., 1975) and the correlation between neuronal degeneration and autonomic impairment (Amorim et al., 1973) have been presented elsewhere.

It appears that an abnormal heart rate response by chronic cardiac chagasic patients is an indication 


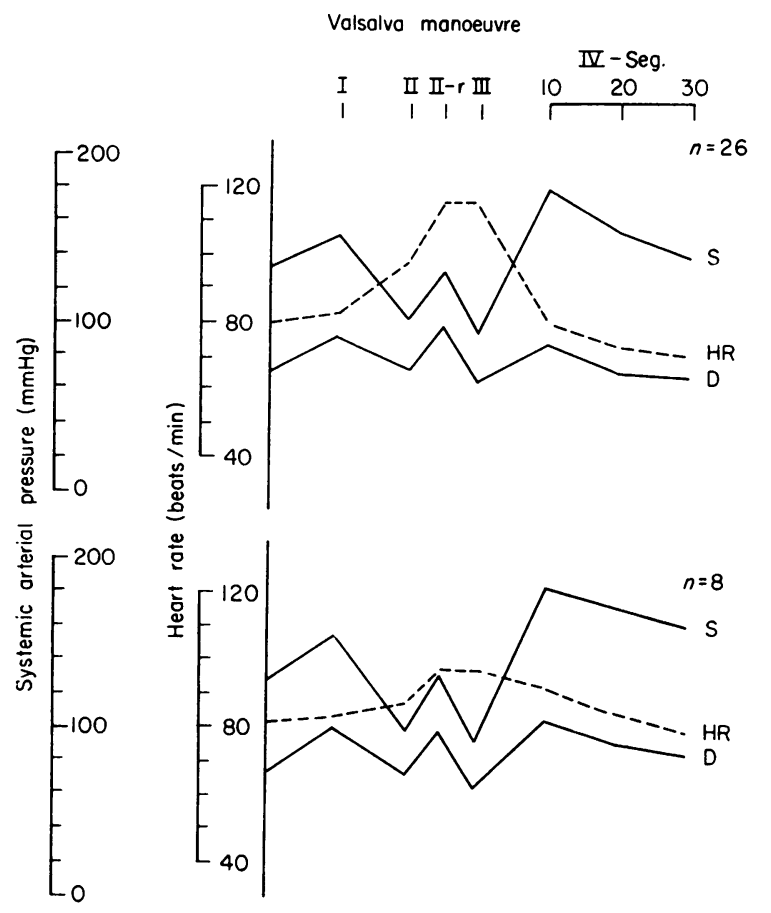

FIG. 1. Continuous recording of the systemic arterial pressure and of the heart rate during performance of the Valsalva manoeuvre (mean values for thirty-four chronic Chagas' heart patients without past or present history of cardiac decompensation). Patients were divided into two groups (a) and (b) according to their cardiac rate responses. Although both exhibited a rebound in systemic arterial pressure at phase IV, bradycardia did not occur in eight patients.

of neuronal degeneration in the sino-atrial region of the heart. These results are in agreement with studies by Köberle (1957) and Teixeira, Teixeira and Santos-Busch (1975) showing neuronal depopulation and lesions of the cardiac nerves. Although a clear distinction appears to exist between chronic cardiac chagasic patients as autonomic control is concerned, there is no demonstrable correlation between autonomic impairment and the degree of heart dysfunction as evaluated on clinical grounds.

Immunofluorescence techniques have been applied by some authors to demonstrate the autoimmune response in Chagas' disease, e.g. reaction of highly specific circulating antibody with endocardium, vascular structure and interstitium of striated muscle (Cossio et al., 1974); other authors have described antiheart antibodies in sera from chagasic patients (Kozma, Jaffé and Jaffé, 1960; Trezza et al., 1975).

Recently, Ribeiro dos Santos $(1976,1977)$ demonstrated antineuronal antibodies containing $95 \%$ IgG and $7 \%$ IgM in the sera of chronic chagasic patients. This suggests that, for a high percentage of patients, the immune response is the result of neuronal destruction from the acute phase of the disease; but that a chronic infection and/or a continuous liberation of auto-antigens from injured tissue may stimulate a continuing autoimmune response.

This latter suggestion would render the development of an abnormal heart involvement more plausible. In fact, those patients with a positive serum only and those with signs of hollow viscera (i.e. megalo-oesophagus) only, could develop or have a 'sub-clinical' type of cardiac disease, i.e. one without heart symptoms and even with a normal ECG.

In several respects chronic Chagas' heart disease may be of interest to the studies related to congestive cardiomyopathy. The most commonly recognized clinical syndrome is of congestive failure with poor systolic function, therefore comparable to the obscure types of cardiomyopathies (Goodwin, 1970; Amorim et al., 1970; Oakley, 1972; Olsen, 1972). But in view of the high incidence of positive serology in people in areas endemic for Chagas' disease, it is possible that this disease is over-diagnosed on account of congestive cardiomyopathy.

The differential diagnosis between chronic Chagas' heart disease and congestive cardiomyopathy may be difficult in the living patient, but at post-mortem the apical aneurysm of Chagas' disease is frequent and distinctive (Andrade, 1956; Köberle, 1968). These apical aneurysms of the left ventricular cavity can be seen clearly during contrast visualization of the heart chambers. Although it is not clear how far the antibodies against myocardial structures are involved with the aetiology and pathogenesis of Chagas' disease, Cossio et al.'s (1974) results are of great interest because in certain cases, chronic Chagas' heart disease can be considered as unlikely when the serum $\gamma$-globulin factor which reacts with endocardium and vascular structures is absent. Also the fact that patients with cardiomyopathies of obscure aetiology respond differently from those with Chagas' disease strengthens the evidence for the specific loss of autonomic control in the latter (Amorim et al., 1970).

But a large number of patients are asymptomatic or have minor symptoms and the diagnosis is eventually confirmed by ECG. At rest they have normal cardiovascular dynamics. This may be considered as one 'experimental model' for the better understanding of congestive cardiomyopathy. It should be emphasized that the chronic stage and its clinical manifestations are established some decades after the acute phase. The cause of death in chronic Chagas' heart disease is attributed to myocardial failure, arrythmias, and the thromboembolic complications as in congestive cardiomyopathy. 
It is recognized that the screening of an asymptomatic population of chronic cardiac chagasic patients is feasible and therefore endomyocardial biopsy should be seriously considered (Olsen, 1975; Olsen and Florio, 1976). What cellular and subcellular evidence is there of changes developing from an 'early' stage (minor or no symptoms) to an 'established' (congestive) stage? Also what are the prognostic implications of high incidence of bundle branch block and of the immunological processes as in congestive cardiomyopathy? (Loogen and Kuhn, 1976; Bolte and Crothey, 1976).

Reports from different geographical areas suggest that hypertrophic obstructive cardiomyopathy and endomyocardial fibrosis are not confined to any particular locality, and it is quite obvious that nowadays in South America this is a matter of pure scientific interest.

In order to clarify the subject and hoping that a clinical presentation would lead to its increased recognition, Guimarães et al., (1971) reported a few cases of endomyocardial fibrosis, eight of which were confirmed at post-mortem. These authors also stressed the difficulty of making a differential diagnosis between endomyocardial fibrosis, Chagas' heart disease, rheumatic heart disease, and pulmonary schistosomiasis, especially when the first is associated with arterial pulmonary hypertension.

\section{Acknowledgment}

D. S. Amorim was a Visiting-Scientist supported by the Conselho Nacional de Pesquisas, Brasil (Proc. 0678/77). The assistance given by Mrs Elza Menezes is hereby fully acknowledged.

\section{References}

Amorim, D.S., Mello de Oliveira, J. A., Meira de Oliveira, J.S., Manço, J.C., Gallo JR, L., Marin Neto, J.A. \& Köberle, F. (1975). Heart block in Chagas' disease. Arquivos brasileiros de cardiología, 28, 79.

Amorim, D.S., Chambers, R.J., Beck, W., Somers, K., Manço, J.C. \& Gallo JR, L. (1970) Comparative observations of the impairment of autonomic responses in chronic Chagas' heart disease and in African myocardiopathies. Cardiologia, 55, 321.

Amorim, D.S., Godoy, R.A., Manço, J C, TanaKa, A. \& Gallo JR, L. (1968a) Hemodynamics in Chagas' disease. Amorim, D.S., Godoy, R.A., Manço, J.C., TanaKa, A. \& Gallo JR, L. (1968a) Hemodynamics in Chagas' disease Archivos brasileiros de cardiologia, 21, 1.

Amorim, D.S., Godoy, R.A., Manço, J.C., Tanaka, A. \& Gallo JR, L. (1968b): Effects of acute elevation in blood pressure and of atropine on heart rate in Chagas' disease. Circulation, 38, 289.

Amorim, D.S., Mello de Oliveira, J.A., Manço, J.C., Gallo JR, L. \& Meira de Oliveira, J.S. (1973) Chagas' heart disease. First demonstrable correlation between neuronal degeneration and autonomic impairment. Acta cardiologica, 28, 431.

ANDRADE, Z.A. (1956) A lesão apical do coração na miocardite cronica chagásica. Hospital, 50, 803.
Andrade, Z. A. (1973) Patologia do sistema excito-condutor do coração na miocardiopatia chagásica crônica. Tesis Faculdade de Medicina da Universidade Federal da Bahia, Salvador, Brasil.

Bolte, H.D. \& Grothey, K. (1976) Cardiomyopathies related to immunological processes. Myocardial Failure, p. 266. Springer-Verlag, Berlin.

Britto, I. \& VASCONCElos, E. (1954) Necrotizing arteritis in megoesophagus. Revista do Instituto de medicina tropical de São Paulo, 1, 195.

Chagas, C. \& Villela, E. (1922) Forma cardiaca da trypanosomiase americana. Memorias do Instituto Oswaldo Cruz, 14, 5.

Cossio, P.M., Diez, C., Szarfran, A., Kreutzer, E., Candiola, G. \& Arana, R.M. (1974) Chagasic cardiopathy; demonstration of a serum gamma globulin factor which reacts with endocardium and vascular structures. Circulation, 49, 13.

Dias, E., Laranja, E.S. \& Nobrega, G. (1945) Doença de Chagas. Memorias do Instituto Oswaldo Cruz, 43, 495.

Gallo Jr, L., Marin Neto, J.A., Manço, J.C., Rassi, A. \& AMORIM, D.S. (1975) Abnormal heart rate responses during exercise in patients with Chagas' disease, Cardiology, 60, 147.

Gilbert, A. (1977) The pattern of urbanization. Latin American Development, p. 83. Penguin Books Ltd. Harmondsworth.

Goodwin, J.F. (1970) Congestive and hypertrophic cardiomyopathies. Lancet, i, 731.

Guimarães, A.C., Esteves, J.P.S. \& Macedo, V. (1971) Clinical aspects of endomyocardial fibrosis in Bahia, Brazil. American Heart Journal, 81, 7.

HutT, M.S.R. (1972) Pathology of the cardiomyopathies: geographical aspects Postgraduate Medical Journal, 48, 738.

KöberLe, F. (1957) Die chronische Chagaskardiopathie. Virchows Archiv für pathologische Anatomie und Physiologie und für klinische Medizin, 330, 267.

KöBERLE, F. (1963) Enteromegaly and cardiomegaly in Chagas' disease. Gut, 4, 399.

Köberle, F. (1968) Chagas' heart disease. Pathology. Cardiology, 52, 82.

Kozma, D., JAFFE, R. \& JAFFÉ, W.G. (1960) Estudo experimental sobre a patogenia das miocardites. Archivos brasileiros de cardiologia, 13, 155.

Laranja, F.S., Dias, E., Nobrega, G. \& Miranda, A. (1956) Chagas' disease. A clinical epidemiologic and pathologic study. Circulation, 15, 1035.

LAurenti, R. \& FonsecA, L.A. (1976) A mortalidade por doenças cardiovasculares no municipio de São Paulo em um período de 30 anos (1940-1969). Archivos brasileiros de cardiología, 29, 85.

Loogen, E. \& KuHN, H. (1976) Classification and natural history of primary cardiomyopathies. Myocardial Failure, p. 232. Springer-Verlag, Berlin.

Manço, J.C., Gallo JR, L., Godoy, R.A., Fernandes, R.G. \& AMORIM, D.S. (1969) Degeneration of the cardiac nerves in Chagas' disease. Further studies. Circulation, 40, 879.

Marin Neto, J.A., Gallo JR, L., Manço, J.C., Rassi, A. \& Amorim, D S (1975) Postural reflexes in chronic Chagas' heart disease. Heart rate and arterial pressure responses. Cardiology, 60, 345.

Muniz, J., Soares, R.B., Souza, M.A. \& Quintao, L.C. (1970) South American Trypanosomiasis (Chagas' disease) within the concepts of immunopathology. Revista brasileira de malariologia e doenças tropicais, 22, 281.

OAKLEY, C.M. (1972) Clinical definitions and classifications of cardiomyopathies. Postgraduate Medical Journal, 48, 703. 
OLSEN, E.G.J. (1972) Cardiomyopathies clinic-pathologic correlation. In: Cardiovascular Clinics, vol. 4, no. 2, p. 240. F. A. Dover.

OLSEN, E.G.J. (1975) Pathological recognition of cardiomyopathies. Postgraduate Medical Journal, 51, 277.

Olsen, E.G.J. \& Florio, R.A. (1976) Cellular and subcellular morphology of biopsy material. Myocardial Failure, p. 175. Springer-Verlag, Berlin.

Pedreira De Freitas, J.L. (1965) Molestia de Chagas como problema de saude publica no Brasil. Revista da Associação medica brasileira, 11, 513.

PUfFeR, R.R. \& GRIFFITH, G.W. (1967) Pattern of urban mortality. Report of the Inter-American Investigation of Mortality. Pan-American Health Organization, Washington D.C. 151, 139.

Puigbo, J.J., Nova Rhode, J.R., Garcia Barrios, H., SuÁrez, J.A. \& Gil YéPes, C. (1966). Clinical and epidemiological study of chronic heart involvenent in Chagas' disease. Bulletin of the World Health Organization, No. $34,655$.

Ribeiro dos Santos, R., Ramos de Oliveira, J.C. \& Rossi, M.A. (1976) Antibodies to neurones in chronic Chagas' disease. Transactions of the Royal Society of Tropical Medicine and Hygiene, 70, 167.

RIBEIRo dos SANTOS, R. (1977) Imunopatologia da doença de Chagas. In: Progressos na Imunologia das Parasitoses, p. 82. Sociedade Brasileira de Medicina Tropical. Brasilia.
Rosenbaum, M.B. \& Alvarez, A.J. (1955) The electrocardiogram in chronic chagasic myocarditis. American Heart Journal, 50, 492.

Teixeira, A.R.L., Teixeira, L. \& Santos-Busch, G.A. (1975) The immunology of experimental Chagas' disease. IV. Production of lesions in rabbits similar to those of chronic Chagas' disease in man. American Journal of Pathology, 80, 163.

TORRes, C.M. (1941) Sobre a anatomia patológica da doença de Chagas. Memorias do Instituto Oswaldo Cruz, 36, 391,

Tranchesi, J., Grimberg, M., Maffa, P.J., Spiritus, M.O. \& Serro Azul. G. (1971) Os blosqueios das divisoes do ramo esquerdo (hemibloqueios). Conceitos. Archivos brasileiros de cardiologia, 24, 77.

Trezza, E., Tucci, P.J.E., Buffalo, E. \& Montenegro, M.R.G. (1975) Anticorpos antimiocardio na doença de Chagas crônica. Correlação entre a sorologia e a electrocardiografia. Archivos brasileiros de cardiologia, 28, 328.

UNITED Nations Economic Commission for LATIN AMERICA (1969) Industrial Development in Latin America, Economic Bulletin for Latin America 14, Second half of 1969.

World Health Organization (1960) Chagas' disease. Report of a Study Group. WHO Technical Report Series, No. 202. World Health Organization, Geneva. 